\title{
Thinking On The Margin: A Classroom Experiment
}

\author{
Joann Bangs, College of St. Catherine, USA
}

\begin{abstract}
In this paper I describe a homework assignment paired with a classroom experiment to help students see the benefits of marginal analysis.
\end{abstract}

Keywords: classroom experiments, marginal analysis

\section{INTRODUCTION}

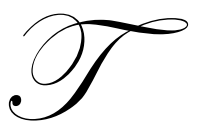

here is a growing body of work to show that the use of experiments can help improve students' performance in economics classes. Durham, McKinnon, and Schulman (2007) did an extensive study of the use of classroom experiments in principles of microeconomics and principles of macroeconomics classes. In their study, they compared a variety of measures for students that participated in courses that incorporated classroom experiments to students in courses that did not incorporate classroom experiments. Their findings show that courses incorporating classroom experiments can have several beneficial effects for students. In their study they looked not just at overall student performance, but also looked at performance related to various types of learning styles. They found that on average student performance improved in classes using experiments regardless of learning style, though the benefit is greater for some learning styles. A second finding is related to students' attitudes towards economics. They measured attitude towards economics both at the beginning and the end of the term. They took these measurements both in a lecture only course and in a course that incorporated classroom experiments. Those students in the course using classroom experiments had a significantly more favorable attitude towards economics at the end of the term. A third finding relates to retention of the material. They tested these groups of students on these concepts later in an upper level business course. They found that students that had participated in the courses using classroom experiments retained more of the concepts than other students. The findings of Durham, McKinnon and Schulman are consistent with other studies such as Dickie (2000) and Emerson and Taylor (2004). Both of these studies have also shown significant improvements in TUCE (Testing of Understanding in College Economics) scores associated with classroom experiments.

I have also found classroom experiments to be useful in my own courses. I have found them to be helpful in getting students to learn and retain information as well as increasing their interest in the material. When I find students struggling with a particular concept, I often turn to classroom experiments for help. In this paper, I describe a homework assignment paired with a short classroom experiment to help students with a concept I had historically observed as difficult for the students.

One of the most important concepts we teach in principles classes is the idea of 'thinking on the margin.' It can also be one of the most difficult to get across. One of the most telling examples for me comes in trying to get students to learn the profit maximizing condition for perfectly competitive firms. I have tried a variety of methods to get students to see why we should look for the quantity where price is equal to marginal cost, but have frequently been disappointed at the significant number of students that do not remember this condition. I often observe students trying to compute profit (even when they don't have enough information to do so) instead of computing marginal costs. I developed a short classroom experiment paired with a homework assignment that has been useful in my classes in getting students to see the value of working with marginal costs. 


\section{EXPERIMENT}

The first step of this exercise is to give students a homework assignment ${ }^{1}$ to calculate different types of costs for a fictional company. The class has discussed how to calculate the various different types of costs in the class previous to receiving the homework assignment. Although the company information in the assignment is fictional, it is designed to have realistic cost structures. It is in the spirit of a context rich problem where a student could see that an actual company could make these types of calculations. The assignment gives information on several fixed and variable costs (including opportunity costs), but does not label them as such. The students must use the information they are given to recognize and calculate fixed costs and variable costs. They must also compute total costs, average fixed costs, average variable costs, average total costs and marginal costs for a several different levels of output. The students are asked to complete this work outside of class time. On the day the work was due, the students compared answers in groups to help each other understand their mistakes. At the end of the group discussion, I made sure all students had a correctly filled out chart of costs for our fictional company. I have found that this discussion can be completed in about ten minutes.

The next step of the process is to discuss some of the basic ideas of perfect competition. It is important that students understand the idea of perfectly competitive firms as price-takers before the experiment begins. However, the profit-maximizing condition of price equal to marginal cost should not be discussed before the experiment.

To begin the experiment, the students need to have the correct cost information from the fictional company with them. I tell the students ahead of time to bring the completed assignment to class. I also show the cost information on screen using a data projector. Next the students need to be told their role in the experiment. Each student is to view herself ${ }^{2}$ as the owner of a perfectly competitive firm. I remind the students of their motivation as a firm owner - to maximize profits. We review that profits are calculated as total revenue minus total costs, and that total revenue is calculated as price multiplied by quantity. I also emphasize that they are price takers in this experiment, and that we are operating in the short run. Therefore their only decision is how much they want to produce. The students are given several small sheets of paper to record their name and their quantity choice at each round.

The students are told there will be several rounds to the experiment. At the start of each round, I will announce the price at which they can sell their product. Their objective is to choose the quantity that will give them the maximum profit. To prevent the students from simply calculating profit at each announced price, I add in a need for speed. I announce that the first 5 students to turn in the profit maximizing quantity each round will receive a small reward. ${ }^{3}$ I sit at the front of the class and have students come to me and form a line to submit their quantity choice. I make sure that I keep the recording sheets in the order that they were submitted.

When all students have submitted their quantity choice, I put up a new display on screen using the data projector. I add two columns to the existing cost spreadsheet: total revenue and profit at the announced price for each quantity level. I also highlight the entire line of the spreadsheet with the correct quantity level. As I pass out the rewards for the first 5 students to submit the profit maximizing quantity, I use the opportunity to remind students of the first increasing then decreasing pattern of profits.

I then repeat this process with several different prices until it seems that most of the students have caught on to look for the quantity such that marginal cost equals the announced price. In my experience a few students will see the pattern by the second round. By the fourth or fifth round, nearly all of the students will have figured it out. I found students to be very enthusiastic about the experiment. I observed a few students running to get their quantity choice submitted in the first five by the second round and several more joining the rush by the third round.

The discussion afterwards is the most important part of this process. I asked students to tell me how they went about choosing their quantity. I have found students to be quite excited to point out that all you needed to do

\footnotetext{
${ }^{1}$ The assignment is attached the appendix.

${ }^{2}$ I developed this experiment at the College of St. Catherine which admits only women to its baccalaureate degree programs.

${ }^{3}$ I used tootsie rolls in my class, but any inexpensive treat for the students will work.
} 
was find the quantity where the marginal cost was equal to the price I announced. That observation leads quite nicely into a discussion of why we should pay attention to marginal costs. I continue the class with the standard lecture material that I do for perfectly competitive firms.

I have found the entire process of running the experiment to take less than fifteen minutes in a class of about thirty students. I think the experiment could be easily adapted to significantly larger classes by using classroom clickers instead of paper recording of their quantity choices.

\section{CONCLUSION}

Although I have not done any formal testing to compare retention of the material explored in the experiment, I do believe the experiment helped students in this area. There seemed to be fewer students struggling with using this concept. In those remaining cases where I observed students continuing to struggle with this concept, referring them back to this experiment seemed to help them recall the required information.

\section{APPENDIX}

\section{Cost Calculation Problem \\ ECON 2610}

You own a business that produces widgets. You must pay the following daily bills to operate your factory:
- $\quad$ Rent-- $\$ 15$
- Utilities-- $\$ 2$
- $\quad$ Insurance--\$3

You took out a loan to buy the equipment you use in your factory. On a daily basis your loan payment is $\$ 5$.

The raw materials used to make widgets cost $\$ 0.50$ per widget. These materials are easily obtainable. You are able to purchase exactly the amount of raw materials you need for production each day.

The time you spend managing your business could otherwise be spent working at another job. You know that you could earn $\$ 150$ per day if you chose to work at another job.

You must hire labor to produce widgets. You are paying $\$ 8$ per hour to your employees. Your employees are all temporary workers. You can choose to hire your workers for as few or as many hours a day as you want.

The number of widgets you are able to produce depends on how many hours of labor you hire.

\begin{tabular}{cc} 
Widgets Produced in a Day & Hours of Labor Needed \\
\cline { 1 - 2 } 100 & 20 \\
110 & 20.5 \\
120 & 21.5 \\
130 & 23 \\
140 & 25 \\
150 & 27.5 \\
160 & 30.5 \\
170 & 34 \\
180 & 38 \\
190 & 42.5 \\
200 & 47.5 \\
210 & 53 \\
220 & 59 \\
& 91
\end{tabular}




$\begin{array}{lc}230 & 65.5 \\ 240 & 72.5 \\ 250 & 80 \\ 260 & 88 \\ 270 & 96.5 \\ 280 & 105.5 \\ 290 & 115 \\ 300 & 125\end{array}$

Use all of this cost information to fill in the cost chart. Please round off all amounts to two decimal places (e.g. \$4.53).

\section{Cost Chart}

\begin{tabular}{|c|c|c|c|c|c|c|c|}
\hline Quantity & Fixed Cost & $\begin{array}{c}\text { Variable } \\
\text { Cost }\end{array}$ & Total Cost & $\begin{array}{c}\text { Average } \\
\text { Fixed Cost }\end{array}$ & $\begin{array}{c}\text { Average } \\
\text { Variable Cost }\end{array}$ & $\begin{array}{c}\text { Average } \\
\text { Total Cost }\end{array}$ & $\begin{array}{c}\text { Marginal } \\
\text { Cost }\end{array}$ \\
\hline 100 & & & & & & & \\
\hline 110 & & & & \\
\hline \multirow{2}{*}{\multicolumn{8}{|c|}{$\frac{120}{130}$}} \\
\hline & & & & & & & \\
\hline \multicolumn{8}{|l|}{140} \\
\hline \multicolumn{8}{|l|}{150} \\
\hline \multicolumn{8}{|l|}{160} \\
\hline \multicolumn{8}{|l|}{170} \\
\hline \multicolumn{8}{|l|}{180} \\
\hline \multicolumn{8}{|l|}{190} \\
\hline \multicolumn{8}{|l|}{200} \\
\hline \multicolumn{8}{|l|}{210} \\
\hline \multicolumn{8}{|l|}{220} \\
\hline \multirow{2}{*}{\multicolumn{8}{|c|}{$\frac{230}{240}$}} \\
\hline \multirow{2}{*}{\multicolumn{8}{|c|}{$\frac{240}{250}$}} \\
\hline & & & & & & & \\
\hline \multicolumn{8}{|l|}{260} \\
\hline \multicolumn{8}{|l|}{270} \\
\hline \multicolumn{8}{|l|}{280} \\
\hline 290 & & & & & & & \\
\hline 300 & & & & & & & \\
\hline
\end{tabular}

\section{AUTHOR INFORMATION}

Joann Bangs earned her B.S. in Economics from the University of Wisconsin-Madison, next spent a few years working for the Board of Governors of the Federal Reserve System, and then went on to earn both her M.A. and her $\mathrm{Ph} . \mathrm{D}$. in Economics from the University of Minnesota. Her areas of specialty in economics are international trade and monetary theory. She has presented her work in these areas at several international conferences. Her current research interests include fair trade programs, the relationship between free trade agreements and the environment, and economics education. She is currently an assistant professor of economics at the College of St. Catherine in St. Paul, MN.

\section{REFERENCES}

1. Bangs, J. (2007). Teaching perfect and imperfect competition with context-rich problems. Social Science Research Network. Retrieved from http://ssrn.com/abstract=1024000 
2. $\quad$ Becker, W.E. \& Watts, M. (2001), Teaching Methods in the U.S. Undergraduate Economics Courses. Journal of Economic Education 32(3), 269-279.

3. Dickie, M. (2006), Do classroom experiments increasing learning in introductory microeconomics? Journal of Economic Education 37, 267-288.

4. Durham, Y., McKinnon, T. \& Schulman, C. (2007), Classroom experiments: Not just fun and games. Economic Inquiry 45(1), 162-178.

5. Emerson, T.L. \& Taylor, B. A. (2004), Comparing student achievement across experimental and lectureoriented sections of a principles of microeconomics course. Southern Economic Journal 70, 672-693.

6. Noussair, C., \& Walker, J. (1998), Student decision making as active learning: Experimental economics in the classroom. In W. Becker \& M. Watts (Eds.), Teaching economics to undergraduates: Alternatives to chalk and talk (49-77). Cheltenham, UK and Northampton, MA, USA: Edward Elgar. 
NOTES 